\author{
VYZDRYK VITALIY, \\ Hetman Petro Sahaidachnyi National Army Academy (Lviv, Ukraine) \\ e-mail:v.vyzdryk@gmail.com,ORCID 0000-0001-5427-5825 \\ MELNYK OLEKSANDRA, \\ Hetman Petro Sahaidachnyi National Army Academy (Lviv, Ukraine) \\ e-mail: melnyko@ukr.net, ORCID 0000-0003-3497-4148 \\ MURAVSKIY OLEG, \\ Ivan Krypiakevych Institute of Ukrainian Studies \\ of the National Academy of Sciences of Ukraine (Lviv, Ukraine); \\ Hetman Petro Sahaidachnyi National Army Academy (Lviv, Ukraine) \\ e-mail:oleg-muravskiy@ukr.net,oRCID0000-0002-2776-5156
}

\title{
AGRARIAN LEGISLATION OF INTERWAR POLAND: SPECIFICITIES OF ITS IMPLEMENTATION IN EASTERN GALICIA
}

Reforming the legal framework of the agrarian legislation of the Second Polish Republic lied in the need to improve socio-economic changes in the system of agrarian land-use. An important basis for this process was supposed to be the creation of a proper legal framework, which, by ensuring the inviolability of private land ownership, created opportunities for the formation and strengthening of farms and would contribute to the elimination of landlessness and land hunger. The implementation of the laws of 1919 and 1920 in the agricultural sector was extremely slow, which forced to seek new ways and approaches to its reforming. In view of the difficult political situation in the eastern and southeastern provinces, taking into account the demands of political forces for reforming land relations in the interest of the peasants, the Sejm adopted a new law on the "Implementation of Agrarian Reform", which came into force in December 1925. This legislative act determined the basic parameters of agrarian sector reforming up to 1939. Although Poland's agrarian legislation largely protected the interests of large landowners, it at the same time contributed to the creation of new farms, improved the mechanism of legal registration of land rights, which strengthened civilized market relations in the economic sector. Separate legislative acts $(1923,1928,1932$ years) normalized the elimination of strip cropping and strip farming (comasation), which slowed the development of intensive agriculture; regulated leasing relations in the agricultural sector, which contributed to its transition to market conditions of functioning; allowed land reclamation works with the aim of optimizing the use of soil potential. State agrarian legislation and government policy had exacerbated national and social contradictions in society. Warsaw's intention to change the quantitative relation of the Ukrainian and Polish populations in favor of the latter through the resettlement of colonists from the Polish ethnic territory to western Ukrainian lands, which were supposed to create strong households and become an important social and political support of the authorities, had failed.

Key words: Eastern Galicia; agrarian legislation; Poland; interwar period; reforms; comasation; parcelation; settlement

\section{Introduction}

The creation of the Second Polish Republic and the post-war socio-economic ruin exacerbated the need to solve a number of problems in the area of land-use. One of them was an increase in the land deficit in consequence of the agrarian overpopulation of Poland. The land question was one of the main issues, and the solution of the dilemma whether the Polish state would be revived largely depended on the solution of this question. The need to reform the agricultural system of the country was caused by the backwardness of its agriculture from many European countries. The process of agrarian transformation in Poland appeared to be a lengthy, complicated and controversial one. This was largely caused by its legal frame- work. The formation of the legal framework for land reform in Poland created a formal legal basis for its implementation in Ukrainian lands where this process had its own specificities. For the Polish state, the agrarian question in Eastern Galicia had become not only socio-economic but also political problem. This was due to the fact that the nationally and socially enslaved Ukrainian peasantry was largely owned by Polish landowners. The economic structure of the Polish and Western Ukrainian villages required a fundamental restructuring. The policy of colonization of Galicia and Volhynia was determined not only by the laws of July 10, 1919 and July 15, 1920, which outlined the national philosophy of agrarian policy, but also by special legislative acts of December 17, 1920, which 
determined the specificities of its implementation in the eastern suburbs of the state.

The source of the study is documents reflecting Poland's legal framework regulating agrarian reforms in Galicia. They were published not only in separate editions, but also in government newspapers such as "Dziennik Ustaw Rzeczypospolitej Polskiej".

At the present stage, an attempt to analyze the legal basis of land reforms has been made by several domestic researchers (Vasiuta, 2010, Vyzdryk, 2013, Smolei, 2003). Among Polish scientists, the studies of Czesław Brzoza (Brzoza, 2001) and Ryszard Torzecki (Torzecki, 1989) attract attention. Many aspects of this problem, especially of a legislative nature, still remain unexamined.

The purpose of this study is to reveal the legal framework of agrarian land-use of the Second Polish Republic and the special aspects of their implementation in the East-Galician village, influence on the socio-economic situation of the region.

\section{Methods}

The theoretical and methodological basis of the study is represented by the principles of scientific knowledge (historism, objectivity, systemacity, comprehensiveness, entirety) and fundamental developments of leading scientists in the fields of world history and economic theory. The tasks of the work were solved by an interdisciplinary combination of general scientific and special-historical methods (analysis, synthesis, chronological, structuralsystematic, logical, comparative, historical-comparative, historical-systematic, retrospective, etc.).

\section{Results}

For the reestablished Polish state, the Law on Agrarian Reform of July 10, 1919 was the first important step in resolving the agrarian question. However, this document had a declaratory nature, so it was not even published in the government press body "Dziennik ustaw Rzeczypospolitej Polskiej", so it did not actually come into obligative force. However, its provisions determined the general principles of the agrarian system of the Polish Republic, which had to be implemented in Eastern Galicia in a specific way, although the state-legal status of the region at that time had not yet been determined by international factors

The "Land Reform Fundamentals" contained "exceptional provisions" aimed at colonization of Ukrainian lands and polonisation of Ukrainians. They had to be implemented not only by the district land offices, the state agricultural bank, but also by the owners of the landlords' estates. In accordance with the provisions of this document, a state land fund was created from the free arable lands of Galicia which had been left without owners because of the wars. The character of redemption and parceling (the sale of land by parcels - small land plots) parts of landlords' estates that exceeded the maximum of land ownership also had its own specificities: while in Poland the maximum size was 180 hectares, for Eastern Galicia, where ethnic Ukrainians lived, is was 400 hectares. Surplus of the land was seized for redemption and subject to parceling and sale to peasants (Zuliak, 2002: 41). Thus, alongside the legislative initiatives, an administrative-executive vertical, which had to ensure their implementation in practice, was formed. The central profile body was the Main Land Administration, which in 1923 was transformed into the Ministry of Agrarian Reforms. It had function of administration and oversight concerning all issues related to the restructuring of the agrarian system: law drafting, control of parceling and colonization, coordination activities of the State Agricultural Bank, etc. The powers of its head were equal to the post of a minister. The Main Land Commission was established at the Main Land Administration to provide judicial oversight in matters of agrarian system reforming and to consider complaints and controversial questions. For the preparation and holding events related to the restructuring of the land system, district land administrations and commissions were formed on the ground at the level of the province, in the poviats - poviat land administrations and commissions. At the level of gmins gmin land commissions were established to facilitate the implementation of decisions of higher authorities in the territories of the villages that were part of them (Brzoza, 2001: 131). Under the Polish Ministry of Agriculture, a Colonial government, which had to implement agrarian transformations in the appropriate direction, was created (Borkowski, 1981: 134).

During the Sejm debates on the problem of agrarian reform, Polish politicians constantly emphasized the national-state significance of agrarian reform. So, at the July 7, 1919 meeting of the Sejm "Piast" Party representative J. Dabski emphasized that "in the Kresy, large land ownership should be parceled as quickly as possible among Polish peasants, because therein lies the national significance of agricultural reform" (Wojciechowski, 1965: 20). The head of the Polish state J. Piłsudski also called for transfer of the land to the property of those who made it "Polish" 1

With this conceptual approach, Poland's political leadership could not allow land in Eastern Galicia to become the object of free market economic relations. Therefore, on September 1, 1919, the Council of Ministers adopted an order prohibiting the free circulation of land in these territories. Permission for its buying and selling had to be issued by the regional commission for land circulation, which was located in Lviv. After the submission of the land commissions and district land administrations, the Main Land Administration in Warsaw issued permits for the land parceling - both to individuals (landowners) and parcel societies and colonist banks ${ }^{2}$.

To control agrarian colonization, a Land National Court was formed to monitor that during the parceling process the land was received by the Polish owners. The bureaucratic system of land reform management made it possible to clearly control the process of agrarian settlement ( $V y z d-$ ryk, 2013: 5).

When implementing the reform in Galicia, the scheme contained in the "Land Reform Fundamentals" was adjusted by the already mentioned Act of July 15, 1920 on the "Implementation of Land Reform", which directed the colonization and parcelization in 36 Galician poviats for the benefit of not so much the local peasantry as Polish colonists

Thus, by the end of September 1921, more than 160,000 hectares of land had been transferred to the property of Polish settlers who had arrived in Eastern Galicia from ethnic Polish lands. The most intensive colonization processes took place in Berezhany, Brody, Buchach, Zbarazh, Zboriv, Zolochiv, Kamianka-Buzka, Pidhaitsi, Radekhiv, Rohatyn, Skalat, Sokal, Ternopil poviats and it

1 Львівське воєводське управління, м. Львів. 1921-1939 рр. Державний архів Львівської області (далі - ДАЛО). Fond 1, List 10 File 1412 Pages 24-25. [Lviv Provincial Administration, Lviv. 1921-1939 State archive of Lviv region]

2 ДАЛО. Fond 1, List 52 File 2856 Pages 19-20. [State archive of Lviv region]. 
was due to the better quality of land in these areas (Vyzdryk, 2013: 6-7)

After the adoption of the Land Reform Act and until the elimination of the Land Restoration Authority (from July 1920 to September 1921), the formation of Polish colonies on the lands of 300 folwarks (64\%) had been controlled or financed by the Lviv Agrarian-Siege Society and the Halych Landlord Credit Bank. Another part of the folwarks -176 $(36 \%)$, which parceled part of their land, were under the control of the Landowners Union, the Landowners Union Bank, the Land Protection Joint-Stock Partnership, the Landlord Bank for Kresy of the Joint-Stock Partnership in Łańcut, the Polish Parceling Bureau in Lviv, the Podilskyi Landlord Union, the Discount Bank in Lviv. According to statistics, at that time Ukrainian peasants had been able to acquire no more than 10 thousand hectares of land of speculators of landlords' land parceled 1919-1921 (Pavlykovskyi, 1922: 18).

Along with civil colonization, the establishment of households of military settlers of the farm type was expected on a slightly different financial and economic basis. On December 17, 1920, for the practical implementation of military-colonization policy in the northeastern provinces, the Polish Sejm approved two so-called "Kresy laws" about the transfer of land in some poviats of Poland into state ownership and the provision of land to soldiers of the Polish army. The state fund also included "ownerless" land of private owners, particularly peasants, who during the First World War and civil wars were forced to leave their native land with entire villages and volosts in a number of poviats. Refugees who had not return to their place of residence until April 1921 were deprived of their right to pre-allocation of land (Vyzdryk, 2013: 7).

The first of mentioned laws provided for the procedure for the formation of a state land fund for conducting agrarian reforms in the eastern provinces. According to its provisions, all the former state landed property of tsarist Russia, the Peasant Bank, the majorat estates and public foundations were alienated into state ownership. The "ownerless" land of private owners was also transferred to the state fund. Article 6 stated that this law was binding 22 Eastern, including Ukrainian poviats ${ }^{3}$.

The second legislative act about giving land to the lower ranks of the Polish army opened the way for Polish military and civilian colonization of Ukrainian lands. In particular, it was intended to provide them land from a state fund formed in accordance with a previous law (Article 1); the free allocation of land to the disabled people and to soldiers who fought as volunteers and distinguished themselves in the front service (Article 2). The size of such plots of land should not exceed 45 hectares. Other categories of citizens could receive land for payment in the form of $30-100 \mathrm{~kg}$ of rye and the payment could be delayed on period of five years. It was envisaged to provide the colonists, especially the military, with free government subsidies and assistance with inventory, seeds and building materials. Specific authorities were designated to implement the provisions of the law ${ }^{4}$. By the way, it prohibited migrants to sell and

\footnotetext{
3 Ustawa z dnia 17 grudnia 1920 r. o przejeciu na własność Państwa ziemi w niektórych powiatach Rzeczypospolitej Polskiej. (1921). Dziennik Ustaw Rzeczypospolitej Polskiej (DURP). Nr. 4. Poz. 17. pp. 38 39. [Act of December 17, 1920 on taking over the ownership of your land in some poviats of the Republic of Poland]. 4 Ustawa z dnia 17 grudnia 1920 r. o nadaniu ziemi żołnierzom Wojska Polskiego. (1921). DURP. Warszawa. Nr. 4. Poz. 18. pp. 4041. [Act of December 17, 1920 on giving land to soldiers of the Polish Army]
}

redistribute landed properties for 25 years without the permission of the authorities.

To facilitate the creation of estates (settlements), a special "settlement fund", which provided low-interest loans to the colonists, was organized, and the "soldier's fund" provided loans in cash or in kind to the demobilized. It is noticeable that control over the implementation of the law about settlement was laid at the Ministry of Military Affairs, which had to work together with the Ministry of Land Reforms (Vasiuta, 2010: 189-190). It should be emphasized that the so-called "Kresy Laws" were adopted when Ukrainians and Belarusians did not have their representation in Sejm of the Second Polish Republic. The government neglected numerous protests of Ukrainians and representatives of other national minorities; it embarked on a path of realization of important tasks for the state and the titular nation at the expense of the people defeated on the fronts of the war.

Poland's economic policy pursued important social and political objectives, which in particular consisted in changing of the quantitative relation of the Ukrainian and Polish populations in favor of the latter. The government sought to solve the problem of agrarian overpopulation in the Polish ethnic territory and to increase the economic and political influence of the state on Western Ukrainian lands. Colonization was one of the important methods of agrarian policy, as Polish settlers had to become an important social and political support of the Polish authorities in Eastern Galicia.

Changes in the agrarian sector were extremely slow and controversial, so the situation of the vast majority of the peasant mass remained difficult. This forced the search for new approaches to the implementation of the legislative acts of 1919 and 1920. Influential party-political groups and parliamentary fractions demanded the revision and improvement of agrarian legislation. Following intense debate during consideration of various projects, on August 20, 1925, the Sejm approved a new law entitled "Implementation of Agrarian Reform" which came into force on December 28 of that year (Ohanowicz, 1926: 487).

This legislative act needs a more detailed analysis, because it had determined the basic parameters for reforming the agricultural sector until 1939. In total, about a hundred governmental and parliamentary normative and executive acts that changed and improved certain aspects of Poland's agrarian system had been adopted (Torzecki, 1989: 46).

Article 1 of the law on the "Implementation of Agrarian Reform" stated that the agrarian system of Poland had to be based on strong, healthy, high-performing farms of different types, sizes and forms of ownership. According to its provisions, the modernization of the agrarian system provided for: the creation of new independent farms; increase of existing small-scale farms to the size of independent ones; creation of small farms for the production of garden-vegetable production; creation of suburban pieces of land for the needs of workers, employees, other categories of urban dwellers; providing the necessary conditions to improve the agrarian culture system, in particular agricultural schools, specialized societies (Ohanowicz, 1926: 488).

The provisions of this legislative act determined the principles of the formation and use of land reserves, however, most of them concerned the order of parceling of land (the "parceling law"). Land ownership standards were clearly regulated here. For suburban, industrial and agricultural areas of central Poland these standards should not exceed 60 and 80 hectares, respectively, but 
for the eastern provinces this figure was 300 hectares. These rules did not take into account the areas under construction, roads, gardens, individual categories of forests and ponds (Smolei, 2003: 19).

The law defined the rules and procedure for parceling of all landed property which exceeded the specified boundary standards: private, church, state and also unprofitable farms. However, the following was exempted from parceling: a) highly productive specialized farms on animal husbandry, seed, fodder production, etc.; b) forest areas where industrial farming was conducted; c) farms where industrial crops were grown, including potatoes (up to 350 hectares), sugar beet (up to 700 hectares), etc. The annual Parceling Fund was set at 200 thousand hectares; if this norm was not reached, the unparceled lands were included in the plan next year ${ }^{5}$.

Surplus of land in private land ownership was subject to obligatory redemption. Their owners were obliged to submit declarations describing all property on the territory of the state and had the right to determine which possessions left in their use and which was for sale in accordance with the state established amount of payment which was determined by the county land commissions. The owner received part of the money in cash, and the rest was divided into "rati" (parts): the first was in the form of $100 \%$ securities; the second - in the form of $70 \%$ of capitalized land rent. The norms of cash and noncash expenses, the procedure for withdrawing annual interest on "rati" from bank accounts etc. were specified ${ }^{6}$.

The law of August 20,1925 determined the procedure for the acquisition of parceled plots. Preference was given to persons capable of rational farm management. The benefits (purchase of the parcel out of turn) were received by soldiers of the Polish army, the disabled people the families of the fallen soldiers, as well as agricultural workers who worked on the estates subject to the parceling. Deserters, state criminals and persons who had been sentenced for more than two years were deprived of the right to acquire the parcels ${ }^{7}$.

Limit sizes of parceled land for different types of users were established: for newly established farms - up to 20 hectares; for garden-vegetable production - up to 5 hectares; for workers and employees in suburban areas and industrial centers - up to 1 hectare. Financial assistance for land buyers was conditioned by their form of ownership. In the state parceling, the initial payment in settling the land contract through land commissions or agricultural bank was set for the landless at $5 \%$ of the value of the land; for smallholders - $10 \%$, and for other categories $-25 \%$. They could get a loan for terms of 20 to 41 years with an annual interest rate to $6 \%$. In private parceling, loans could be issued by the State Land Bank, which provided a system of preferential loans for poor households (Yova, 1954: 63).

Depending on the form of land ownership, the mechanisms of parceling were determined: for state-owned land it had to occur through land administrations and the land bank, as well as through specially empowered organizations and unions; in private landed property it was conducted by the owners under the control of local authorities.

The law of "Implementation of Agrarian Reform" stimulated the development of capitalist market relations

\footnotetext{
5 Ustawa z dnia 28 grudnia 1925 r. o wykonaniu reformy rolnej. (1926). DURP. Warszawa. Nr. 1. Poz. 1. pp. 2-19. [Act of December 28,1925 on implementation of the land reform]

6 Ibid.

7 Ibid.
}

in agriculture. Limiting large landed properties, it contributed to the formation of a land market, deepened the differentiation of peasant farms. However, it had many gaps and imperfect provisions. In particular, it recorded, but did not explain the nature of such types of farms as "independent", "small", "dwarf", which affected the conditions of obtaining loans and the possibilities and size of obtaining additional parcels. Similarly, the legislator did not provide clear interpretations of different types of farms: "industrial", "intensive", "fattening", etc., which paved the way for abuse in determining the category of land ownership. The lack of protection mechanisms against the "nondivisibility" of farms led to the process of their further fragmentation (Fialkowski, 1937: 12).

In addition to parceling, a number of legislative acts defined and regulated the nature of relations with other areas of agrarian reform, which, at the same time, were also linked to land ownership and various forms of landuse. Approving its conceptual line on the delivery (transfer) of land to property for different categories of peasantry, on June 24, 1924, the Polish Sejm issued a law regulating property right to land of former officials, long-term tenants and so-called "free people". Its provisions determined pricing approaches for these categories of owners who had to pay the quitrent eight times more than existing in 1913 for the purchase of land. If they were unable to pay the entire estimated value of the land at once, they could take a loan from the Agricultural Bank for 12 years at $6 \%$ per annum (Wł udyka, 1994: 55).

Despite the tendency towards democratization of agrarian legislation, many acts that protected the interests of large landowners more than impoverished peasants were adopted in interwar Poland. This refers to, in particular, two laws of the Sejm, adopted on March 18, 1932. The first one concerned the protection of the rights of owners who acquired unarable soil. It provided for their purchase with the agreement of the owners at a lower cost (Wł udyka, 1994: 56).

The second legislative act regulated the ownership of land. Its adoption resulted from the fact that about $60 \%$ of the purchasers of the parcels, having paid the previous owners the agreed costs, did not acquire legal ownership of the land, although in fact they freely disposed it. The absence or inaccurate execution of the acts of sale and purchase of land caused a disorder in the parceling campaign and difficulties in taxation. Therefore, the provisions of the document obliged and improved the mechanism of legal registration of the land right (Wł udyka, 1994: 55), which contributed to the establishment of civilized market relations in the economic sector.

The Polish legislator normalized such an important component of the restructuring of the land system as land comasation, the essence of which was the elimination of the strip farming, in other words, the compiling of land of one owner located in different places into a single area. The first step in this direction was the Sejm Decree of July 31,1923 , which argued the need to solve this problem in the redistribution of land, which made its owner more independent of the community and contributed to the promotion of economic culture and increased productivity - from the introduction of new methods of soil cultivation to the cultivation of different types of plants etc. The provisions of the law provided that the farm received soils of the same value as were in the previous use, and, if the soil was different, compensation was provided. The forests and land where industrial activities or cultural sites were located was not subject to comasation. At the same time, its implementation included the settlement of other important 
elements of land arrangement: liquidation of easements, division of communal lands, revision of boundaries of individual territorial-administrative units, allocation of areas for public use, reclamation etc. Costs related to the preparation of the relevant project documentation were covered by the owners of the farms ${ }^{8}$.

So, the nature of the comasation work was reviewed and improved by various normative and executive acts. In particular, significant changes in the procedure for their implementing were made by regulation of the Ministry of Agriculture and Agrarian Reforms of June 6, 1935, according to which the corresponding amounts of payments were regulated (Rosloniec, 1927: 445).

The natural and climatic conditions of agriculture in Poland, in particular in the accessed western Ukrainian lands, led to high soil moisture, marshiness of large land areas, which became unfit for cultivation and use for other agricultural and economic purposes. This actualized the need for reclamative works, which were regulated by separate legislative norms. The unsettled, local solution to this problem led to the appearance order by the President of Poland of March 1928, which actualized this case as an important component of the restructuring and improvement of the land system. The document, firstly, required to accelerate the organization of land reclamation and to coordinate the work related to it during land comasation and parceling. Secondly, it obliged the government and local authorities responsible for the land system to make this case planned and strategic. The main financial costs were covered by the state (Vytanovych, 1936: 36).

It soon became clear that land reclamation required many costs, so in early 1931 a government order was issued under which the part of costs (from $20 \%$ to $30 \%$ ) had to be paid by communities and individuals interested in conducting such work (Rosloniec, 1927: 446).

A number of legislative acts had to regulate lease relationships in the agricultural sector, which also contributed to its transition to market conditions. The law on the protection of small land tenants adopted by the Polish Sejm on August 28, 1924 and the law on the purchase of land by small land tenants of March 18, 1932 formally regulated relations in this area. According to their provisions, only those peasants who, on a voluntary agreement with the landowners, leased land up to 5 hectares on vacant lots of landlords, could buy the leased land. However, peasants who unwarranted occupied landlord's lands, which laid abandoned, during the war or after it, and small tenants who were punished "for a crime against the Polish state", which included members of the peasant movement, had no right to buy "hungry" rent, so they "fell out" of the rental relationship system (Rocznik ziem Wschodnich, 1939: 35).

\section{Discussion}

Considering that the vast majority (almost 90\%) of the population of Eastern Galicia were peasants, scientific interest is the study of agrarian policy of Poland during the interwar period, an important component of which was the agrarian legislation that protected the interests of landowners, destroyed the traditional structure of the Ukrainian village and pursued the assimilation and colonization of the Ukrainian population of the region. The formation of the legal framework for conducting land reform in Poland

\footnotetext{
${ }^{8}$ Ustawa z dnia 31 lipca 1923 r. o scalaniu gruntów.(1923). DURP. Warszawa. Nr. 92. Poz. 718. pp. 1050-1056. [Act of July 31, 1923 on land consolidation (1923). DURP. Warsaw. No. 92. Item 718 pp. 1050-1056.]
}

ISSN 1728-9343 (Print)

ISSN 2411-3093 (Online) created the formal-legal basis for its implementation on Ukrainian lands. For the Polish state, the agrarian question in Eastern Galicia had not only socio-economic but also political content.

\section{Conclusions}

Thus, the reform of Poland's agrarian system largely determined the progress of all social life and the prospects of state-building. Its conduct was determined by a number of socio-political and socio-economic factors, in particular the urgent need to improve the land ownership system. An important basis for this had to be the creation of a proper legal framework directed towards ensuring the inviolable private property land rights and improving the forms and ways of its use. Agrarian restructuring of land ownership and land-use was conditioned by a number of factors and provided by law. It was implemented primarily on the basis of a number of laws approved by the Polish Sejm of July 10, 1919, May 7, 1920, July 15, 1920, December 17, 1920, January 10,1922 , July 31,1923 , and July 26,1925 . Although the agrarian legislative acts approved by the Sejm were of a national nature, they had their own Ukrainian specificity. The agrarian legislation of the state and the policy of the government were aimed at preserving the estates of Polish landowners in Eastern Galicia with simultaneous reducing the size of their landed property to a rational level, and on parceled lands strong farms had to be created from colonists removed from indigenous Poland who had to become a social support for the authorities, strengthening land famine and social tension in Eastern Galicia.

\section{REFERENCES}

Pavlykovskyi, Yu. (1922). Zemelna sprava u Skhidnii Halychyni (korotkyi istorychnyi i ekonomichnyi ohliad zemelnoho pytannia ta suchasnyi yoho stan). Lviv. 45 p. (In Ukrainian).

Fialkowski, H. (1937). Uporzadkowanie stanu prawnego drobnych gospodarstw na ziemiach wschodnich. Lublin, 16 p. (In Polish).

Ohanowicz, A. (1926). Ustawa o wykonaniu reform rolney $i$ inne ustawy rolne. Poznan. 504 p. (In Polish).

Rocznik ziem Wschodnich. (1939). Warszawa: Wydawnictwo Zarządu Głównego Towarzystwa Rozwoju Ziem Wschodnich, 96 p. (In Polish).

Wojciechowski, S. (1965). Moje wspomnienia. Paryz: Instytut literacki, 527 p. (In Polish)

Rosloniec, S. (1927). Rozdrobnienie gospodarstw w Polsce. Rolnik ekonomista. Warszawa, 3, 443-456. (In Polish).

Vasiuta, I. (2010). Halytsko-volynske selo mizh svitovymy viinamy. Lviv: Kameniar, 507 p. (In Ukrainian).

Vyzdryk, V. (2013). Polske ahrarne osadnytstvo na zakhidnoukrainskykh zemliakh u 20-kh rr. XX st. Hrani, 6, 4-7. (In Ukrainian).

Vytanovych, I. (1936). Ukrainske selianstvo na shliakhu do pobidy. Istoriia ukrainskoho selianstva. Lviv: Samoosvita, 40 p. (In Ukrainian).

Zuliak, I. (2002). Osoblyvosti polskoi polityky na zakhidnoukrainskykh zemliakh (1919-1939). Naukovi zapysky Ternopilskoho derzhavnoho pedahohichnoho universytetu im. V. Hnatiuka. Seriia: Istoriia. Ternopil. Issue 3. pp. 39-47. (In Ukrainian).

Yova, P. (1954). Borotba trudiashchykh Zakhidnoi Ukrainy za vozz'iednannia z Radianskoiu Ukrainoiu. Lviv. 113 p. (In Ukrainian).

Smolei, V. (2003). Polske tsyvilne i viiskove silskohospodarske osadnytstvo v Zakhidnii Ukraini (1919-1939 rr.). Ternopil: Pidruchnyky i posibnyky, 112 p. (In Ukrainian).

Borkowski, J. (1981). Chł opi Polacy w dobie kapitalizmu. Warszawa, 234 p. (In Polish).

Brzoza, Cz. (2001). Polska w czasach niepodległ ości i II wojny światowej (1918-1945). Krakow, 424 p. (In Polish).

Torzecki, R. (1989). Kwestia ukraińska w Polsce w latach 1923-1929. Kraków: Wydawnictwo Literackie, 467 p. (In Polish). 
Włudyka, T. (1994). "Trzecia droga" w myśli gospodarczej II Rzeczypospolitej. Kraków, 169 p. (In Polish)

Васюта І. Галицько-волинське село між світовими війнами. Львів: Каменяр, 2010. 507 с.

Виздрик В. Польське аграрне осадництво на західноукраїнських землях у 20-х рр. XX ст. Грані. 2013. № 6. С. 4-7.

Витанович І. Українське селянство на шляху до побіди. Історія українського селянства. Львів: Самоосвіта, 1936. 4. III. $40 \mathrm{c}$

Зуляк І. Особливості польської політики на західноукраїнських землях (1919-1939). Наукові записки Тернопільського державного педагогічного університету ім. В. Гнатюка. Серія: Історія. Тернопіль, 2002. Вип. 3. С. 39-47.

Йова П. Боротьба трудящих Західної України за возз'єднання з Радянською Україною. Львів, 1954. 113 с.

Павликовський Ю. Земельна справа у Східній Галичині (короткий історичний і економічний огляд земельного питання та сучасний його стан). Львів, 1922. 37 с.

\section{LIST OF REFERENCE LINKS}

Смолей В. Польське цивільне і військове сільськогосподарське осадництво в Західній Україні (1919-1939 рр.). Тернопіль: Підручники і посібники, 2003. 112 с.

Borkowski J. Chłopi Polacy w dobie kapitalizmu. Warszawa: PWN, 1981. $333 \mathrm{~s}$.

Brzoza Cz. Polska w czasach niepodległości i II wojny światowej (1918-1945). Krakow: Fogra, 2001. 424 s.

Fialkowski H. Uporzadkowanie stanu prawnego drobnych gospodarstw na ziemiach wschodnich. Lublin,1937. $16 \mathrm{~s}$

Ohanowicz A. Ustawa o wykonaniu reform rolney i inne ustawy rolne. Poznan, 1926. $504 \mathrm{~s}$.

Rocznik ziem Wschodnich. Warszawa, 1939. $96 \mathrm{~s}$

Rosloniec S. Rozdrobnienie gospodarstw w Polsce. Rolnik ekonomista. Warszawa, 1927. T. 3. S. 443-456

Torzecki R. Kwestia ukraińska w Polsce w latach 1923-1929. Kraków: Wydawnictwo Literackie, 1989. 467 s.

Włudyka T. "Trzecia droga" w myśli gospodarczej II Rzeczypospolitej: koncepcje Adama Doboszyńskiego a program obozu narodowego. Kraków: Universitas, 1994. 169 s.

Wojciechowski S. Moje wspomnienia. Paryz: Instytut literacki, 1965. $527 \mathrm{~s}$

Виздрик Віталій,

Національна академія сухопутних військ імені Петра Сагайдачного (м. Львів, Украӥна) e-mail:v.vyzdryk@gmail.com, ORCID 0000-0001-5427-5825

Мельник Олександра,

Національна академія сухопутних військ імені Петра Сагайдачного (м. Львів, Україна) e-mail:melnyko@ukr.net, ORCID 0000-0003-3497-4148

Муравський Олег,

Інститут украӥнознавства ім. І. Крип'якевича НАН України (м. Львів, Украӥна);

Наиіональна академія сухопутних військ імені гетьмана Петра Сагайдачного (м. Львів, Україна)

e-mail: oleg-muravskiy@ukr.net, ORCID 0000-0002-2776-5156

\section{АГРАРНЕ ЗАКОНОДАВСТВО МІЖВОЄННОїПОЛЬЩІ: ОСОБЛИВОСТІ ЙОГО ВПРОВАДЖЕННЯ В СХІДНІЙ ГАЛИЧИНІ}

Реформування нормативно-правової бази аграрного законодавства Другої Речі Посполитої полягало в необхідності вдосконалення соціально-економічних змін в системі аграрного землеустрою. Важливим підґрунтям цього процесу мало стати створення належної законодавчої бази, яка, забезпечуючи непорушність приватної власності на землю, відкривала можливості для утворення та зміцнення фермерських господарств, сприяла б ліквідації безземелля і малоземелля. Реалізація законів 1919 і 1920 років в аграрному секторі відбувалася вкрай повільно, що змушувало шукати нових шляхів і підходів до його реформування. Зважаючи на складну політичну ситуацію у східних і південно-східних воєводствах, враховуючи вимоги політичних сил щодо реформування земельних відносин в інтересах селян, сейм ухвалив новий закон під назвою "Про виконання аграрної реформи", який набрав чинності в грудні 1925 р. Цей законодавчий акт визначав основні параметри реформування аграрного сектора аж до 1939 р. Незважаючи на те, що аграрне законодавство Польщі більшою мірою захищало інтереси великих землевласників, але в той же час сприяло створенню нових фермерських господарств, удосконалило механізм юридичного оформлення права на землю, що утверджувало цивілізовані ринкові відносини в економічному секторі. Окремі законодавчі акти (1923 р., 1928 р., 1932 р.) унормовували ліквідацію вузькосмужжя і черезсмужжя (камасація), що сповільнювали розвиток інтенсивного землеробства; регулювали орендні відносини в аграрному секторі, що сприяло його переходу на ринкові умови функціонування; дозволили проведення меліоративних робіт з метою оптимального використання потенціалу ґрунтів. Аграрне законодавство держави й політика уряду вкрай загострили національні i соціальні протиріччя в суспільстві. Прагнення Варшави до зміни кількісного співвідношення українського та польського населення на користь останнього, за рахунок переселення із польської етнічної території колоністів на західноукраїнські землі, які повинні були створити міцні господарства й стати важливою соціальною та політичною опорою влади - зазнали краху.

Ключові слова: Східна Галичина; аграрне законодавство; Польща; міжвоєнний період; реформи; камасація; парцеляція; осадництво.

(C) Vyzdryk Vitaliy, Melnyk Oleksandra, Muravskiy Oleg

Надійшла до редакції: 11.06.2019

Прийнята до друку: 31.07.2019

СХІД № 4 (162) липень-серпень 2019 р.

ISSN 1728-9343 (Print) ISSN 2411-3093 (Online) 